\title{
Reply - Genetic polymorphisms and cerebrovascular disease in children with sickle cell anemia from Rio de Janeiro, Brazil
}

\author{
Resposta - Polimorfismos genéticos e doença cerebrovascular em crianças com anemia \\ falciforme do Rio do Janeiro, Brasil
}

\begin{abstract}
Isaac Lima da Silva Filho', Ana Claudia Celestino Bezerra Leite ${ }^{4,2}$, Patrícia Gomes Moura ${ }^{5}$, Georgina Severo Ribeiro $^{6}$, Andréa Cony Cavalcante ${ }^{5}$. Flávia Carolina Marques de Azevedo ${ }^{5}$, Maria José de Andrada-Serpa ${ }^{3}$
\end{abstract}

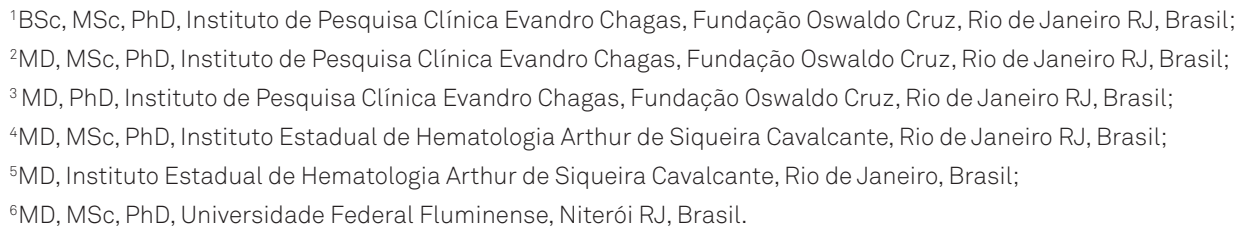

\section{Dear Editors,}

We thank Belisário and colleagues ${ }^{1}$ for their interest in our study. We are open to further discussions on this relevant subject. We believe that the diversity of clinical manifestations observed in patients with sickle cell anemia (SCA) is a challenging issue that needs to be better understood, and only cohort and multicenter cooperative studies will increase the knowledge about SCA in our population. Here, we clarify the issues raised as follows:

\section{ALPHA THALASSEMIA}

As explained in our paper, alpha thalassemia is considered the only genetic polymorphism clearly associated with a specific clinical manifestation in SCA. The majority of reports have stated that co-inheritance with SCA confers a protective effect against cerebrovascular disease (CVD) $)^{2-7}$. Furthermore, a decrease in the frequency of abnormalities in transcranial Doppler has been observed in patients with alpha thalassemia ${ }^{8,9}$. Although our results did not show statistical significance, children with alpha thalassemia have had fewer CVD events $15.8 \%$ (3/19) than those without alpha thalassemia $84.2 \%(16 / 19)$. Therefore, the results of the two studies are in agreement, and we suppose that the absence of statistical significance was due to the sample size.

\section{$\beta^{\text {S GENE CLUSTER HAPLOTYPES }}$}

1. Our family studies indicated that no child in our sample was a beta thalassemia carrier. All were homozygous for SCA. All samples classified as Atypical haplotypes were amplified and showed a restriction pattern consistent with this classification according to the method used ${ }^{10}$.

2. The correlation between $\beta^{\mathrm{S}}$ haplotypes and CVD is still controversial probably due to the small number of studies with a restricted number of patients. However, it is clear that different populations present peculiarities that characterize and differentiate them from each other. Bernaudin et al. report that in France, $\beta^{\mathrm{S}}$ haplotypes were not related to $\mathrm{CVD}^{9}$. In Brazil (Salvador), at least one chromosome Bantu was observed in patients with a history of $\mathrm{CVD}^{11}$. In the United States, a higher risk for CVD development was observed in children with four or more alpha genes whose haplotypes were Bantu/Benin, Atypical or Bantu/Bantu than in children with other associations ${ }^{6}$. We believe that a detailed genetic study of $\beta^{\mathrm{s}}$ haplotypes might contribute to increase the knowledge of their influence on CVD in patients with SCA. Therefore, we are performing gene sequencing of all Bantu/Atypical samples; the obtained sequences will be compared with the samples of other haplotypes of the studied children.

3. In this study, we did not consider the association between hematological features and CVD. 
Finally, we agree that differences between the two studies $^{1,12}$ may be related to the study design, as well as to the sample size. With respect to CVD, we would like to emphasize that our definition has high scientific accuracy, because we followed the current guidelines for the classification of CVD in sickle cell disease.

\section{References}

1. Belisário AR, Rodrigues CV, Martins ML, et al. Coinheritance of $\alpha$-thalassemia decreases the risk of cerebrovascular disease in a cohort of children with sickle cell anemia. Hemoglobin 2010;34:516-529.

2. Adams RJ, Kutlar A, McKie VC, et al. Alpha thalassemia and stroke risk in sickle cell anemia. Am J Hematol 1994;45:279-282.

3. Gill FM, Sleeper LA, Weiner SJ, et al. Clinical events in the first decade in a cohort of infants with sickle cell disease. Blood 1995;86:776-783.

4. Ohene-Frempong K, Weiner SJ, Sleeper LA, et al. Cerebrovascular accidents in sickle cell disease: rates and risk factors. Blood 1998;91:288-294

5. Neonato MG, Guilloud-Bataille M, Beauvais P, et al. Acute clinical events in 299 homozygous sickle cell patients living in France. Eur J Haematol 2000;65:155-164.

6. Sarnaik SA, Ballas SK. Molecular Characteristics of Pediatric Patients with Sickle Cell Anemia and Stroke. Am J Hematol 2001;67:179-182.

7. Steinberg $\mathrm{MH}$. Predicting clinical severity in sickle cell anaemia. $\mathrm{Br} J$ Heamatol 2005;129:465-481.
8. Hsu LL, Miller ST, Wright E, et al. Alpha talassemia is associated with decreased risk of abnormal transcranial Doppler ultrasonography in children with sickle cell anemia. J Pediatr Hematol Oncol 2003;25: 622-628.

9. Bernaudin F, Verlhac S, Chevret S, et al. G6PD deficiency, absence of \{alpha\}-thalassemia, and hemolytic rate at baseline are significant independent risk factors for abnormally high cerebral velocities in patients with sickle cell anemia. Blood 2008;112:4314-4317.

10. Sutton M, Bouhassira EE, Nagel RL, et al. Polymerase chain reaction amplification applied to the determination of beta-like globin cluster haplotypes. Am J Hematol 1989;32:66-69.

11. Adorno EV, Zanette A, Lyra I, et al. Clinical and molecular characteristics of sickle cell anemia in the northeast of Brazil. Genet Mol Biol 2008;31:621-625.

12. Silva-Filho IL, Leite ACCB, Moura PG, et al. Genetic polymorphisms and cerebrovascular disease in children with sickle cell anemia from Rio de Janeiro, Brazil. Arq Neuropsiquiatr 2011;69:431-435. 